\title{
Quantitative Management for Portfolio Human Resource Change
}

\author{
Jun Ma , Yonghu Yang \\ Research Administration \\ Dalian Neusoft University of Information \\ Dalian, China \\ maj@neusoft.edu.cn
}

\author{
CuiLing Zhang \\ Neusoft Corporation \\ Dalian, China \\ zhangcl@neusoft.com
}

\begin{abstract}
This document explains and demonstrates how to manage the change of the people in portfolios management with quantitative data references to achieve the main idea of multi projects management of overall profits increase within acceptable risks. (Abstract)
\end{abstract}

Keywords- Portfolio management;Human resource management;Change management,;Quantitative management (key words)

\section{INTRODUCTION}

While we manage our company or department, we need to balance the projects in order to get the best rewards and control the risks. We want to get the best use of our resource especially human resource, and when we need to change them we need to considerate many factors by our experiences, there are a lot of issues occur by only use our brain and we need some better quantitative references from the bottom to help with our decision-making.

The portfolio management is a methodology to find an appropriate balance with the profit and risks. It is no doubt that we can't set up the project with high risk and low profit. That means there is a threshold with risks and incomes. So the problem has turned into a question with risk and income limitation how to get a max profit within limit human resources, or if the profits are equivalent which risk is lower.

Basic Equations:

Acceptable profit limit per project $=$ Threshold_ profit according to your company

Acceptable risk limit per project $=$ Threshold_ risk according to your company

Project Profit (i) = Contract Amount (i) + Strategy Income (i) - Project Cost (i) - Tax (i)

Project Risk (i) = Quality Risks (i) + Cost Risks (i) + Delivery Risks (i)

Total Profit $=$ PP $(1)+$ PP $(2)+\ldots+$ PP $(\mathrm{i})+\ldots+$ PP $(\mathrm{m})$ $=\sum P P(i)$

Total Risk $=$ PR $(1)+P R$ $(2)+\ldots+$ PR $(\mathrm{i})+\ldots+$ PR $(\mathrm{m})$ $=\sum \mathrm{PR}(\mathrm{i})$

$\mathrm{F}$ (balance) $=$ Max $($ Total Profit) or Min (Total Risk while Profits are equivalent)

Steps: To realize this aim we need to complete the following processes step by step.

1. Set up an acceptable risk and profit threshold.

2. Get the information of employee's abilities.

3. Estimate and take strategy income into account of the project profit.
4. Analysis the software requirement scope reference use case point method.

5. Calculate the QCD base information and figure out the project risks considerate the quality, cost and delivery factors. 6. Work out the max profits within the risk threshold while we need change people resources.

These definitions and processes will be discussed in detail in the following sections.

Conditions and Limitations: We suppose that the plan of the projects had already made and some resources had been assigned to it and then there is a new project or new activity need a special human resource; The resource cycle is closed that the outsourcing human resources are not considered in this discussion.

NOTE: In order to make the expression understood easily, we use letter ' $i$ ' to express the project and use letter ' $j$ ' to express the factor or info inside the project.

\section{SET UP THRESHOLD OF RISK AND PROFIT}

\section{A. Acceptable Profit Limit per Project:}

It is the threshold for all the projects that if we can't get enough income we will not recommend to change the resources. And the lowest value is depending on the company's strategy as different company could accept different profit percentage of investment. As a general values we set it as $15 \%$.

\section{B. Acceptable Risk Limit per Project}

It is the threshold for all the projects that if the project it self's total risk is too high we will give up the change of resources to keep the project with acceptable risk level. Like the profit, the acceptable risk is in depending with the company's tactics and we assume the risk exponent is not more than 5.The way to count the risk will be discuss below..

\section{GET ALL EMPLOYEE's ABILITY INFORMATION AND DEVICE'S INFORMATION}

Ability Map:Before get the employee's ability information, we need to get an organizational ability map first which list the ability group, ability code, ability name, ability level, ability level descriptions, activity duration(common time spend on an activity) and rotate duration( the duration need to be added for the rotate). Like Table 1:

Employee's Cost Information: Get all employees' cost information. Like Table 2: 
Employee's Ability Information: Get all employees' ability information. Like Table 3:
Get All Device's Information: Get all devices' cost information. Like Table 4:

TABLE I. ABILITY MAP

\begin{tabular}{|c|c|c|c|c|c|c|}
\hline Group & Code & Name & Level & Descriptions & $\begin{array}{l}\text { Activity } \\
\text { Duration }\end{array}$ & $\begin{array}{l}\text { Rotate } \\
\text { Duration }\end{array}$ \\
\hline Management & Ma1 & & & & & \\
\hline & $\ldots$ & & & & & \\
\hline \multirow[t]{7}{*}{ Technology } & Ta1 & $\begin{array}{l}\text { Java } \\
\text { UCP Development }\end{array}$ & 1 & $\begin{array}{l}\text { Not familiar with } \\
\text { this business. }\end{array}$ & 3 & 1 \\
\hline & & & 2 & $\begin{array}{l}\text { Know a little about } \\
\text { this business, less } \\
\text { than } 6 \text { months } \\
\text { experiences }\end{array}$ & 2.5 & 0.5 \\
\hline & & & 3 & $\begin{array}{l}\text { Work level: Could } \\
\text { work with others, } \\
6 \sim 12 \quad \text { months } \\
\text { experiences }\end{array}$ & 2 & 0.25 \\
\hline & & & 4 & $\begin{array}{l}\text { Design level: Could } \\
\text { work singly, } \\
1 \sim 4 \text { years } \\
\text { experiences. }\end{array}$ & 1.5 & 0.25 \\
\hline & & & 5 & $\begin{array}{l}\text { Expert level: Could } \\
\text { guide others work, } \\
\text { more than } 5 \text { years } \\
\text { experiences. }\end{array}$ & 1 & 0.25 \\
\hline & Ta2 & $\begin{array}{l}\text { Distributed system } \\
\text { Development }\end{array}$ & 1 & & & \\
\hline & & & $\ldots$ & & & \\
\hline \multirow[t]{3}{*}{ Business } & Ba1 & Accounting & & & & \\
\hline & $\mathrm{Ba} 2$ & CRM & & & & \\
\hline & $\ldots$ & & & & & \\
\hline
\end{tabular}

TABLE II. DEVICE’S INFORMATION

\begin{tabular}{|l|l|}
\hline Employee & Cost per day(RMB) \\
\hline E1 & 480 \\
\hline E2 & 450 \\
\hline E3(Outsourcing) & 400 \\
\hline$\ldots$ & \\
\hline
\end{tabular}

TABLE III. EMPLOYEE'S ABILITY

\begin{tabular}{|l|l|l|}
\hline Employee & Code & Level \\
\hline E1 & Ma1 & 5 \\
\hline E1 & Ma2 & 3 \\
\hline E1 & Ta1 & 1 \\
\hline E2 & Ta2 & 3 \\
\hline E2 & Ba1 & 4 \\
\hline E3(Outsourcing) & Oa1 & 3 \\
\hline$\ldots$ & & \\
\hline
\end{tabular}

TABLE IV. DEVICE'S INFORMATION

\begin{tabular}{|l|l|}
\hline Device & Cost per day(RMB) \\
\hline D1 & 100 \\
\hline D2 & 200 \\
\hline$\ldots$ & \\
\hline
\end{tabular}

\section{ESTIMATE STRATEGY INCOME}

A company's permanently development has tightness relationship with the strategy plan to make sense from an overall business perspective. Put strategy factors into account of portfolio management will get a better influent with the real control. There are so many method and tools to set up a strategy which we will not discusses here, what we concerned is that how to make strategy affect the project management directly. The way is to count how much investment could we accept if we will not get any real income from this project and we still could continue with the project only because it is a critical part of the company's strategy? Other words, how much will we put into R\&D for 
this strategy and how many percent could this project take for this strategy? This is the strategy income in fact. So we could simply turn strategy into a kind of income, for example 0 to 500,000 RMB.

\section{ANALYSIS REQUIREMENT SCOPE}

\section{A. Requirement Scope}

A requirement is a need, expectation, or obligation. It can be stated or implied by an organization, its customers, or other interested partied. There are many typed of requirements. Some of these include quality requirements, customer requirements, management requirements, product requirements, and legal requirements [1]. The requirements consist of functional and non-functional requirements and the non-functional requirements include technical requirements and non-technical requirements. We just name non-technique requirements as environmental requirements.

Requirements $=$ Functional requirements + Non-functional requirements

Non-function requirements $=$ Technical requirements + Environmental requirements

Every requirement has its weight and durations which are useful in counting QCD and risk.

\section{B. Functional Requirement}

We can reference the method of Use Case Point partly to analysis the scope first. Draw down the use case diagram to get the outline of the system. Find out the actor and use case and identify the direct relation between them.

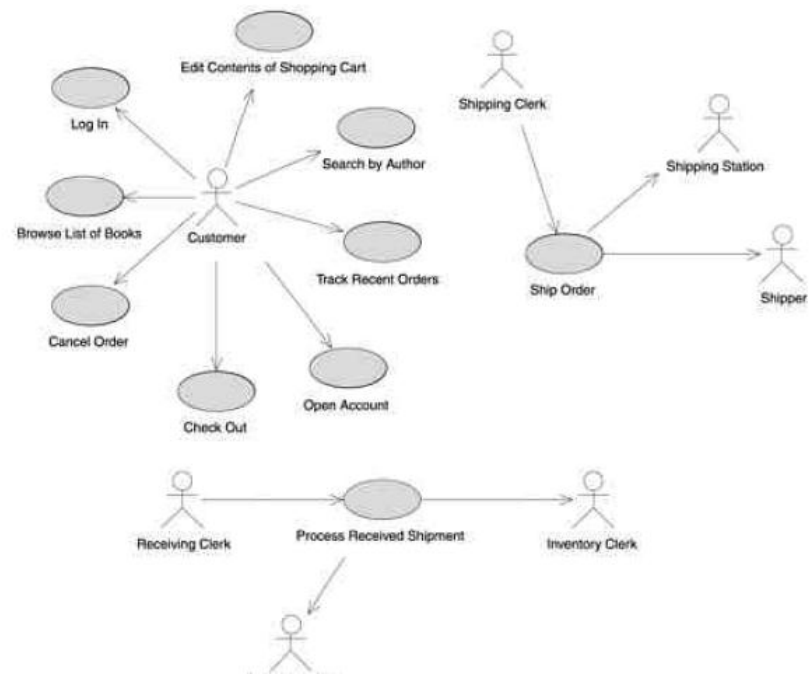

Figure 1. Use Case Diagram

Note: actors include not only people who interact with the system but also include the system or devices which interact with the system.

Specific the Use Case weight of use case:

- Simple use case -3 or fewer transactions: weight $=1$

- Average use case -4 to 7 transactions: weight 2

- Complex use case - more than 7 transactions: weight 3

\section{Technical Requirements Factor}

The technical requirement maybe requested as an overt or covert. Those technical requirements have different factors and each technical factor has different weight and need level. See Table 5:

TABLE V. TECHNICAL FACTORS

\begin{tabular}{|l|l|l|l|}
\hline $\begin{array}{l}\text { Technical } \\
\text { Factor }\end{array}$ & Description & Weight & $\begin{array}{l}\text { Need } \\
\text { Level }\end{array}$ \\
\hline T1 & Distributed system & 2 & 3 \\
\hline T2 & $\begin{array}{l}\text { Response or throughput } \\
\text { performance objectives }\end{array}$ & 2 & 3 \\
\hline T3 & End-user efficiency & 1 & 3 \\
\hline T4 & Complex internal processing & 1 & 3 \\
\hline T5 & Reusable code & 1 & 3 \\
\hline T6 & Easy to install & 0.5 & 3 \\
\hline T7 & Easy to use & 0.5 & 3 \\
\hline T8 & Portable & 2 & 3 \\
\hline T9 & Easy to change third & 1 & 3 \\
\hline T10 & Concurrent & 1 & 3 \\
\hline T11 & Includes Security features & 1 & 3 \\
\hline T12 & $\begin{array}{l}\text { Provides access for thaining } \\
\text { parties }\end{array}$ & 1 & 3 \\
\hline T13 & $\begin{array}{l}\text { Special user } \\
\text { facilities are required }\end{array}$ & \\
\hline
\end{tabular}

\section{Environmental Requirements Factor}

The environmental requirement is a covert requirement which include related with the ability of people or organization and other environmental factors. The Environmental factor is listed below:

TABLE VI. ENVIRONMENTAL FACTORS

\begin{tabular}{|l|l|l|l|l|}
\hline $\begin{array}{l}\text { Environmental } \\
\text { Factor }\end{array}$ & Type & Description & Weight & $\begin{array}{l}\text { Need } \\
\text { Level }\end{array}$ \\
\hline E1 & Labor & $\begin{array}{c}\text { Familiar with } \\
\text { Rational } \\
\text { Unified } \\
\text { Process }\end{array}$ & 1.5 & 3 \\
\hline E2 & Labor & $\begin{array}{c}\text { Application } \\
\text { experience }\end{array}$ & 0.5 & 3 \\
\hline E3 & Labor & $\begin{array}{c}\text { Object- } \\
\text { oriented } \\
\text { experience }\end{array}$ & 1 & 3 \\
\hline E4 & Labor & $\begin{array}{c}\text { Lead analyst } \\
\text { capability }\end{array}$ & 0.5 & 3 \\
\hline E5 & Labor & Motivation & 1 & 3 \\
\hline E6 & Labor & $\begin{array}{l}\text { Stable } \\
\text { requirements } \\
\text { control } \\
\text { capability }\end{array}$ & 2 & 3 \\
\hline E7 & $\begin{array}{l}\text { Full-time } \\
\text { workers }\end{array}$ & 1 & 3 \\
\hline E8 & Labor & $\begin{array}{c}\text { Simple } \\
\text { programming }\end{array}$ & 1 & 3 \\
\hline
\end{tabular}




\begin{tabular}{|l|l|c|l|l|}
\hline E9 & Labor & $\begin{array}{c}\text { language } \\
\text { Tester } \\
\text { understand the } \\
\text { business }\end{array}$ & 1 & 3 \\
\hline E10 & Device & $\begin{array}{c}\text { Require } \\
\text { D1(Printer) }\end{array}$ & 0.25 & 3 \\
\hline E11 & Labor & $\begin{array}{c}\text { Outsourcing } \\
\text { side ability }\end{array}$ & $\cdots$ & 3 \\
\hline
\end{tabular}

\section{GET QCD BASE INFORMATION AND FIGURE OUT} RISKS

Precedence Diagram: Set those requirements as activities (include every use case, technical requirement and environmental requirement), sequence them and draw the network diagrams and record the sequence (next activities). Precedence Diagramming Method (PDM)

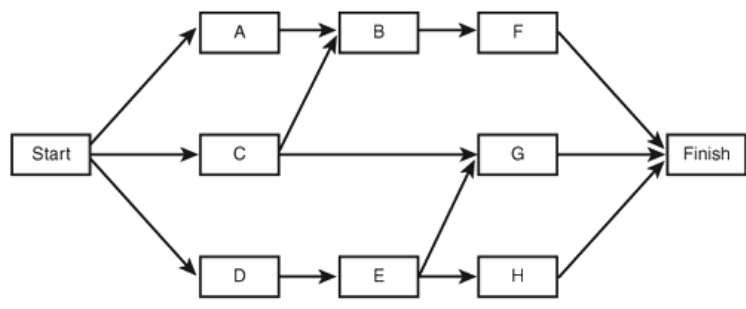

Figure 2. Precedence Diagramming Method

Assign Resources: Find the labor with suitable abilities. Find the suitable device.

Quality: In ISO9000, The quality of something can be determined by comparing a set of inherent characteristics with a set of requirements [7]. The degree of comparing is between the required level and the assigned level for every requirement ' $\mathrm{j}$ ' is:

Quality $(\mathrm{j})=$ Requirement weight $(\mathrm{j}) *$ [Assigned level $(\mathrm{j})$ - Required level(j)]

Cost: Cost estimates can include labor, materials, equipment, and any other direct costs for project activities [8]. Here we do not count indirect costs and simply count the cost of every activity:

$\operatorname{Cost}(\mathrm{j})=$ Cost of Activities $(\mathrm{j})$

Delivery (Critical Path): Fill in the PDM's duration according to the activities type. And the duration of the activity is the assigned labor's level's duration come from Table 1:

Use Case $(\mathrm{j})=$ Use Case Weight $(\mathrm{j}) *$ Duration of Assigned Labor(j)

Technique $(\mathrm{j})=$ Technique Weight $(\mathrm{j}) *$ Duration of Assigned Labor(j)

Environment $(\mathrm{j}$ if Labor $)=$ Environment Weight $(\mathrm{j}) *$

Duration of Assigned Labor(j)

Environment $(j$ if Device $)=0$

Record the activity, predecessor, duration, earliest start date information, like Table 7:
TABLE VII. ACTIVITY INFORMATION

\begin{tabular}{|llll|}
\hline Activity & Predecessor & Duration & $\begin{array}{l}\text { Earliest Start } \\
\text { Date }\end{array}$ \\
\hline A & None & 5 & $9 / 5 / 05$ \\
\hline B & A & 2 & $9 / 10 / 05$ \\
\hline C & A & 3 & $9 / 10 / 05$ \\
\hline D & B & 7 & $9 / 12 / 05$ \\
\hline E & C & 4 & $9 / 13 / 05$ \\
\hline F & D & 1 & $9 / 19 / 05$ \\
\hline G & E, F & 2 & $9 / 20 / 05$ \\
\hline
\end{tabular}

Get the critical path: For each activity, record the Early Start, Early Finish, Late Start, Late Finish and Slack info. From start node to finish node, fill in the early start and early finish info by compute the max early finish of the successor. From the finish nod to start node, fill in the late finish and late start info by compute the min late start info of the predecessor. Use late start minus early start to get the slack info. On critical path slack are all 0.There maybe more than one critical path in the project.

Find the gap between the longest duration and the deadline date duration. Adjust the resource and try the best to fill in the gap, and recount the above QCD info again. At last we can get the finally critical path duration.

Risk: According to ISO 31000, risk is the "effect of uncertainty on objectives", and an effect is a positive or negative deviation from what is expected. So, risk is the chance that there will be a positive or negative deviation from the objective you expects to achieve [10]. There are many factors could cause risk and we just simply consider the QCD risks here for these risk take the $80 \%$ affect.

Quality risk is the amount of every quality which is lower than 2:

Quality Risk (j) = if [Quality (j) $<2$, Quality (j),0]

Cost risk is the ORI miss-distance lower than the project profit limit:

Cost $(\mathrm{i})=\sum[\operatorname{Cost}(\mathrm{j})]$

Project Profit (i) = Contract Amount (i) + Strategy Income (i) - Project Cost (i) - Tax (i)

ROI (i) $=$ Project Profit (i) $/($ Project Cost (i) + Tax (i)) (19)

Cost Risk (i) $=$ if $\{$ ROI (i) < Profit Limit, [Profit LimitROI (i)]*100, 0$\}$

Delivery risk is the duration between the deadline date duration and the critical path duration:

Delivery Risk (i) $=$ if $\{$ CP Duration (i) $>$ Deadline(i), [CP Duration(i) - Deadline(i)],0\}

Project risk is the summary of quality risks, cost risks and delivery risks:

Project Risk (i) $=$ Quality Risks (i) + Cost Risks (i) + Delivery Risks (i)

If the project risk is higher than the acceptable risk limit per project, then it is not permitted. We must change the resource to get the risk down or just do not begin with this project.

And then we can get the total profit and total risk of our organization: 
Total Profit $=$ PP $(1)+$ PP $(2)+\ldots+$ PP $(i)+\ldots+$ PP $(m)$

$=\sum P P(i)$

Total Risk $=$ PR (1) + PR (2) +... PR (i) + ... PR (m)

$=\sum \mathrm{PR}(\mathrm{i})$

The total risks vary persistently for the risks will turn down with some activities accomplished and the risk will grow up with more new activities appear as time passing by.

\section{GET MAX PROFITS OR MIN RISKS}

Get max profits or min risks is an extra-mum value problem. We could do some adjust to simplify the operation since choose the max profits with acceptable risk will cause a lot of calculate.

If there is a new task asking for a labor resource for specific time, we can traverse the spare resources first and calculate the profits with acceptable risks for this will get more profit than resource change obviously.

If there is no such suitable spare resource available (risk is too high for ability level not reach request), then we should traverse the equipped resource whose ability is higher than the spare resources from the lowest risk project on. And his job may be delayed if possible or be assigned to another human resource that is selected from the lowest risk project according to the rotate. (Restrict: only permit two layer's rotate or else the process will be nested and the usability and efficiency will be affected). Certainly we need to add rotate duration along with this change (list in Table 1). Via the step $3,4,5$ we can get a set of total profit and risk data. Give the top five profit higher resource rotate result to the decision maker for reference.

However since there are still so many factors that we can't turn into numeric factors nowadays, so the result given from this way is not wholly proper for the management. We still need an expert to balance the other factors in reality. According to different company they still need to adjust some of the existing data of factors, weights and duration to fit their requirements. It is a continuous process to accumulate more project knowledge data to improve the objective portfolio management.

\section{SUMMARY}

Project management is an association of the science and a complex system engineer. Get the $20 \%$ main point of high profit and low risk is a key to successfully manage the portfolio. This process just simulates our thought to make the choice with the factor of strategy, requirement, quality, cost, delivery and risk. The quantitative analysis could support decision-maker with a better human resource changing and the final goal could be achieved in the status of dynamic balance.

\section{ACKNOWLEDGMENT}

I would also like to thank all teachers who have helped me to develop the fundamental and essential academic competence. My sincere appreciation also goes to the teachers and students from Neusoft Corporation and Dalian Neusoft University of Information.

\section{REFERENCES}

[1] ISO 9000, 9001, AND 9004 PLAIN ENGLISH DEFINITIONS

[2] Applying Use Case Driven Object Modeling with UML: An Annotated e-Commerce Example,Doug Rosenberg. By Kendall Scott, June 14, 2001

[3] Improving Estimation Practices by Applying Use Case Models. By Bente Anda, Endre Angelvik, and Kirsten Ribu. M. Oivo and S. Komi-Sirviö (Eds.): PROFES 2002, LNCS 2559, pp. 383-397, 2002. Springer-Verlag Berlin Heidelberg 2002

[4] PMP Exam Cram ${ }^{\mathrm{TM}}$ 2,Second Edition By Michael Solomon, 2005

[5] ISO 310002009 PLAIN ENGLISH RISK MANAGEMENT DICTIONARY 